\title{
Ramdeo Medal Bestowed by President of India on Occasion of World Environment Day 1984
}

On the occasion of his receipt of the Ramdeo Medal for Environmental Sciences on World Environment Day 1984, Dr Mostafa K. Tolba, Executive Director of UNEP, addressed the audience of nearly 1,000 in the Vigyan Bhawan, New Delhi, substantially as follows:

Mr President, I am deeply touched by the honour which you bestow on me, and I am also honoured today to share the platform with distinguished friends and colleagues from the World Council For The Biosphere and the International Society For Environmental Education. The Biosphere is more than the thin mantle of earth, vegetation, water, and air, that supports all life on this planet. It is also a concept-an integrating concept - which ties our lives and the life around us to the physical functions of the world. It is only through better understanding of Mankind's relationships with its environment that our long-term prosperity, even survival, can be assumed.

A fundamental quandary which we face is that of meeting the basic needs of our kind without simultaneously destroying the result and resource-base that sustains the environment from which these needs must be met. Governments of 113 nations, often for the first time, faced this quandary in the United Nations Conference on the Human Environment which was held in Stockholm in 1972. They declared their intent to safeguard and enhance the environment for present and future generations. In the intervening years we have learned just how difficult a role that occasion in Stockholm set us. But at least we have defined and developed our ideas. Terms such as environmentally-sound or sustainable development have become common currency-though common chiefly to ourselves in the environmental movement. We now view environmental management as a strategy which interlocks the enhancement and stability of The Biosphere on one hand, and sustainable development on the other. Beyond our constituency we are seeing signs of an increasing understanding of the need for environmental concern, with ever-widening agreement that there is no real conflict between conservation and development - that the stability of our Biosphere depends on using resources that are sustainable and ensuring that they remain so.

\section{Demonstrable Solutions Needed}

This is our received wisdom, but how are we to put these ideas effectively into practice? We may have convinced ourselves, but have we convinced others? I do not believe that we will do so unless we show, first, how this can be done and, second, point to practical examples of where it has been done. In the environmental movement we have been expert at pointing out what is going wrong. We need to add new levels of expertise. We must come up with solutions and we must be able to cite cases where, consciously or unconsciously, sustainable development does work and can have broad appeal. Here in India, hundreds of thousands of villagers and towndwellers have become enthusiastically involved in successful tree-planting movements. In Guyana, local fisherman have become involved in a sustainable-yield approach. Such examples of ecologically-sound development give us hope and find the way open. But the list, though already long, is not nearly long enough.
As I continually stress, nothing will happen to reduce threats to the environment unless a widespread public awareness of key environmental issues is aroused. Environmental education is a crucial need for increasing public awareness. As a former university teacher, I have no doubts about the importance of education; but we must never forget the need to make education meaningful at all levels. From the village level upwards, we must educate people to see that conservation and protection of the environment serves their best interests. With this understanding in mind, I pledge to you that UNEP will march together with all of you in achieving these goals. We must succeed. Future generations depend on it. Working together we will succeed.

\section{Environment Day Message}

Mr President, it is a special privilege for me to introduce my World Environment Day message through this august gathering, honoured by your own presence, and from the country which literally led the Third World in conceiving the real significance of concern over the environment. Your personal commitment, Mr President, and the dedication of your distinguished Prime Minister to the cause, are further testimony of the history of long wisdom that characterized the people of this country. Please permit me now to read out my message to the world.

Each year the world has over 80 million more people to feed, but less good soil to grow crops. The destruction of our soil cover, a truly world-wide phenomenon, is undermining our capacity to feed the human population which is expected to increase by over a thousand million people by AD 2000 . This year some 30 million infants -almost the population of Spain-will die of hunger. Up to 200 million people are severely malnourished, but few make the connection between soil erosion, hunger, and deepening poverty.

Nature can take up to a thousand years to accumulate the type of soil needed to a hoe's depth, but raging monsoons or strong winds can remove all the exposed topsoil in a matter of days. More often the process of destruction is less dramatic - a steadily dwindling fertility to a point where the land becomes useless to the farmer. Technological advances in production of new, highyielding crop strains will achieve little if we fail to save the topsoil. Soil for all practical purposes cannot be renewed. Soil erosion is a natural process, but across vast areas the action of people is speeding up the process far beyond regenerating capacity.

Rich and poor countries alike are menaced. In the United States of America, 40 million hectares have already been damaged beyond any practical repair. Here in India one-third of the arable land is threatened with total loss of topsoil. The reason for soil loss is that we are demanding more than the soil can give. We are misusing the Earth. In the world's drylands, overstocking, ploughing-up of marginal land, and deforestation, are leading to the spread of desert-type conditions. When the inevitable drought strikes, famine results. Each year, deforestation turns some six million hectares into desert or semi-desert. A further 21 millions are reduced to zero economic productivity. World-wide, the livelihood of some 850 million people is threatened. Loss of farming 
land on this scale is closing down our future options. Ominously, the rate of increase in yields of basic crops such as maize, wheat, and soyabeans, is declining.

We can be encouraged that Governments and their people are becoming more and more aware of the dangers, but erosion is still easily winning the race. The scientific and technical solutions are known, now consisting of a great body of knowledge on how to stop desert encroachment and conserve soils. But all too often the poor farmer has no access to even the most basic expertise and technology, and even when they are available, what seems sound economic sense to the planner, fails to appeal to a peasant concerned primarily with feeding his growing family.

\section{Conclusion}

Appropriate land-tenure is crucial. When the farmer feels insecure, the tendency is to mine the land until it is no longer productive, then to move on elsewhere to repeat the process. Involvement is the key: there is an urgent need to involve the villagers at all stages of development. If Governments seriously want their farmers to reduce their herds or to stop ploughing steep slopes or to replant trees, then the authorities must provide proposals that people will accept. If we are to have any realistic hopes of adequately feeding the projected turnof-the-century population of over six thousand million people, Governments must engineer a switch to a more frugal, more conserving, agriculture. If we are to arrest the destruction of our environment, people must be educated to appreciate that it is in their overwhelming self-interest to do so. As the Chinese philosopher Kwand $\mathrm{Zu}$ wrote:

'If you plan for one year, plant rice.

If you plan for ten, plant trees.

If you plan for one hundred years, educate mankind.'

\section{Possible Approach to Explaining Strange Behaviour of Surging Glaciers}

Scientists think they have the answer to what causes the curious behaviour of 'surging glaciers' that accelerate dramatically from time to time, unlike normal slowmoving masses of ice. The cause of such surges has been a major mystery in the understanding of glaciers in general. Now the US National Research Foundation (NSF) has announced that research workers studying a glacier in Alaska have reported that its periodic surges are associated with increases in water-pressures beneath the glacier, which affect its base and cause it to slide very rapidly. The increased pressures are related to changes in the shape and motion of the glacier which inhibit drainage of water along the base of the ice - according to these workers, who think that similar conditions may have contributed to the rapid collapse of some of the huge ice-sheets that covered much of North America and Europe during the Pleistocene Epoch, from about 1.5 million to 12,000 years ago.

The scientists who reported their findings to the NSF are Professor Charles F. Raymond, of the University of Washington, Seattle, Dr William D. Harrison, of the University of Alaska, and Professor W. Barclay Kamb, of the California Institute of Technology, Pasadena. They are studying a mass of ice called the Variegated Glacier - so-named because of the multicoloured rocks piled in front of it as it moves down a valley towards the sea about 30 miles $(48 \mathrm{~km})$ east of the tiny fishing village of Yakuta, lying to the north-west of Juneau. The Glacier is almost 15 miles $(24 \mathrm{~km})$ long and 6,000 feet $(1,829 \mathrm{~m})$ high at its source. It is one of the smaller ones of the surging type, and probably the most studied, having been observed and photographed since about 1900 . Until now, however, no extensive measurements have been made of the behaviour of the Glacier, which surges every 18 to 20 years.

The latest, anticipated surge of the Variegated Glacier started in January 1982, when surface velocities of the ice reached as much as 30 feet ( $c a 9 \mathrm{~m}$ ) a day in early summer and returned to its near-normal velocities of three to six feet per day during the late summer and fall. The glacier began to speed up again in November 1982 , and by spring of 1983 the speed had reached up to 180 feet ( $c a 55 \mathrm{~m}$ ) a day. The surge stopped abruptly in early July, when large amounts of water drained out of the glacier.

A variety of techniques were used to measure the Glacier's movement, including time-lapse photography for which cameras were placed along adjacent walls of the valley. Markers on the ice were surveyed, sometimes as frequently as each hour, during the summer months. Also, holes were drilled through the ice and instruments placed in them to measure water pressure at the base of the Glacier and differences in the flow-rate between the top and bottom layers of ice. Water discharged from the Glacier also was measured, and aerial photographs were taken periodically to monitor the overall movement of the glacier. The Variegated Glacier is in a remote area, where floods from the surge pose no danger. However, other glaciers are near inhabited regions where a surge could threaten lives and property.

RALPH KAZARIAN
National Science Foundation
1800 G Street
Washington
DC 20550
USA.

RaLPH KaZARIAN

National Science Foundation Washington

USA.

\section{World Policy Institute: Programme Description}

\section{Purpose}

The World Policy Institute is a non-profit research and public education organization located in New York City. It formulates practical policy recommendations on United States and world economic and security issues, and promotes them to the policy-making community and the public. Institute programmes stress the develop- ment of 'world policies' — policies that reflect the shared needs and interests of all nations and that can, over time, help to reshape the political and intellectual context within which all governments operate.

The political process in the USA has opened-up considerably in recent years and there is now a fresh opportunity to inculcate new, positive initiatives into the 